\title{
THE BIG FIVE PERSONALITY \\ AND TEMPERAMENT TRAITS AND THEIR CORRELATION WITH STYLES OF COPING WITH STRESS IN THE FIRE BRIGADE OFFICERS
}

\author{
JUSTYNA SZRAJDA
}

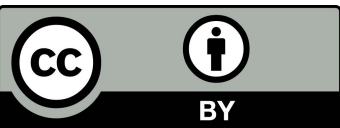

Nicolaus Copernicus University in Torun, Collegium Medicum in Bydgoszcz,

Department of Hygiene, Epidemiology and Ergonomics,

ul. M. Curie-Skłodowskiej 9, Bydgoszcz, Poland

E-mail address: justyna.szrajda@cm.umk.pl

\section{MALWINA TUDOROWSKA}

Nicolaus Copernicus University in Toruń, Collegium Medicum in Bydgoszcz,

Department of Preventive Nursing,

ul. Łukasiewicza 1, Bydgoszcz, Poland

E-mail address: malwina.tudorowska@gmail.com

SŁAWOMIR KUJAWSKI

Nicolaus Copernicus University in Torun, Collegium Medicum in Bydgoszcz,

Department of Hygiene, Epidemiology and Ergonomics,

ul. M. Curie-Skłodowskiej 9, Bydgoszcz, Poland

E-mail address: slawomirkujawski7@gmail.com

MAGDALENA WEBER-RAJEK

Nicolaus Copernicus University in Torun, Collegium Medicum in Bydgoszcz, Department of Physiotherapy, ul. Techników 3, Bydgoszcz, Poland

E-mail address: magdawz@cm.umk.pl

EWA SYGIT-KOWALKOWSKA

Kazimierz Wielki University, Institute of Psychology, ul. Leopolda Staffa 1, Bydgoszcz, Poland

E-mail address: esygit@ukw.edu.pl

\section{ZDZISŁAW KOBOS}

Cardinal Stefan Wyszyński University in Warsaw,

Department of Work Psychology and Stress, ul. Wóycickiego 1/3, Warszawa, Poland E-mail address: z.kobos@uksw.edu.p1 


\title{
JOANNA SŁOMKO
}

Nicolaus Copernicus University in Toruń, Collegium Medicum in Bydgoszcz,

Department of Hygiene, Epidemiology and Ergonomics,

ul. M. Curie-Skłodowskiej 9, Bydgoszcz, Poland

E-mail address: jslomko@cm.umk.pl

\section{MAŁGORZATA TAFIL-KLAWE}

Nicolaus Copernicus University in Torun, Collegium Medicum in Bydgoszcz, Department of Physiology, ul. Karłowicza 24, Bydgoszcz, Poland

E-mail address: malag@cm.umk.pl

\section{PAWE€ ZALEWSKI}

Nicolaus Copernicus University in Toruń, Collegium Medicum in Bydgoszcz, Department of Hygiene, Epidemiology and Ergonomics, ul. M. Curie-Skłodowskiej 9, Bydgoszcz, Poland E-mail address: p.zalewski@cm.umk.pl

\begin{abstract}
Selecting specific professional activities (e.g. a brigade officer) and methods for coping with difficult situations may result from personal predispositions of a given person. Personality is founded on the innate temperament. The way of dealing with stress depends on personality traits whose influence is manifested, amongst other things, in the selection of specific coping styles.

The current study aims to examine the level of correlation between personality and temperament traits with manifested coping styles.

The study examined 58 volunteers - male fire brigade officers. The following tools were used: Personality Inventory, NEO-FFI, Formal Characteristics of Behaviour: Temperament Inventory - Revised Version, FCZ-KT (R) and Coping Inventory for Stressful Situations, CISS.

Emotion-focused coping style for stressful situations correlates with the following traits: positively, with perseveration $(\mathrm{r}=0.5115)$ and with emotional reactivity $(\mathrm{r}=0.4927)$, and negatively, with briskness $(\mathrm{r}=-0.3926)$ and endurance $(\mathrm{r}=-0.5408)$. The task-oriented coping style for stressful situations correlates positively with extraversion $(\mathrm{r}=0.3236)$ and conscientiousness $(r=0.3088)$, and negatively with neuroticism $(r=-0.3368)$ in the NEO-FFI. The emotion-focused coping style for stressful situations is positively correlated with neuroticism (NEO-FFI) $(\mathrm{r}=0.4150)$.

In fire brigade officers, as far as personality traits were concerned, fire brigade officers scored relatively high in extraversion, conscientiousness and low in neuroticism and were likely to demonstrate the task-oriented coping style for stressful situations. Lower levels of perseveration and high levels of briskness and endurance were associated with emotion-focused coping style for stressful situations. Similarly, the tendency to focus on emotions experienced in stressful situations were associated with high level of neuroticism in the study group.
\end{abstract}

Key words: Personality; Temperament; Styles of coping with stress 


\section{INTRODUCTION}

Working as a fire brigade officer is considered a high-risk profession. Job specifications, particularly in rescue and firefighting units, involve exposure to numerous stress-inducing factors (contaminated air, noise, physical exercise, work in confined spaces, responsibility for human life). Considering the above, fire brigade officers should have a higher than average level of physical fitness and required mental predispositions determining their endurance to stress, making quick decisions and, in certain circumstances, the capability of undertaking risky behaviour.

Selecting specific professional activities and coping styles may result from personal predispositions of a given person (Strelau, 2000), where they represent a characteristic, relatively stable way in which a person reacts to stimuli in the environment. Our personality may influence our approach to difficult situations at work, and how we reduce tension associated with the performed roles. The published reports indicate that in uniformed service workers it may act as protection against negative health consequences (Oginska-Bulik, 2005). It should therefore be assumed that personality is a factor playing a role in the development of mental well-being.

Personality is founded on the innate temperament. Temperament traits have a genetic background and are modified - amongst other things - by ongoing learning taking place during the person's development. It is assumed by Strelau that the role of temperament is revealed, in particular, in very difficult or extreme situations with a strong potential for emotional stimulation, but also during professional work (Strelau, 2000).

Theoretical and empirical studies provide convincing arguments for the thesis that a way of coping with stress depends on the personality traits whose influence is manifested, amongst other things, in the selection of specific coping styles (Klonowicz, \& Cieslak, 2004).

As the Authors of meta-analysis on relationship between the personality and coping conclude (Connor-Smith, \& Flachsbart, 2007), personality can affect coping by modulation of the strategies that are the most convenient to implement and by affecting the effectiveness of those strategies. However, the Authors underline the need for further researches on personality and coping: developing a still-limited knowledge in this field may facilitate prevention and intervention programs design (Connor-Smith, \& Flachsbart, 2007). Moreover, temperament traits could play a role in depressive symptoms (Carver, \& Connor-Smith, 2010) and correlation between coping, temperament, and burnout was indicated in some occupational groups, e.g. in health care professionals (Rowe, 1997). Therefore, there is a need to examine the interrelationship between personality and temperament traits with coping styles in stressexposed professional groups, such as fire workers.

The survey design is based on the following research questions:

- Which personality and temperament traits are of the highest intensity in the group of fire brigade officers? 
- What is the relationship between personality traits, temperament traits and coping styles in the studied sample?

\section{MATERIAL AND METHODS}

The study covered 58 healthy volunteers - active male fire brigade officers working at fire brigade units in the Kujawsko-Pomorskie Voivodeship. The study was conducted using standard diagnostic tools for the evaluation of personality, temperament, and reaction to stressful situations. The study was anonymized, so data relating to the subjects' age and seniority were not collected. After completing the test questionnaires, the volunteers put them in a box in the study room.

The following diagnostic tools were used:

1. Personality Inventory (NEO-FFI), developed by P.T. Costa and R.R. McCrae, adapted to Polish conditions by Bogdan Zawadzki, Jan Strelau, Piotr Szczepanik and Magdalena Śliwińska (Zawadzki, Strelau, Szczepaniak, \& Śliwińska, 1998), and serving the investigation of five main personality traits: neuroticism - a factor reflecting emotional adaptation versus emotional imbalance, and determining a predisposition to experience negative emotions; extraversion - describing the number and quality of social interactions and ability to experience positive emotions, a level of energy and activity; openness to experience - a trait determining the predisposition to seek and evaluate life experiences in a positive way, as well as cognitive curiosity and tolerance for novelties; agreeableness - describes positive versus negative attitude to other people; and conscientiousness - reflecting attitude towards work, the level of organization, and endurance and motivation in activities aimed at specific objectives. Each question is assigned 12 test items. The result for each trait ranges from 0 to 48 points. When interpreting results for the scales, a classification of scores expressed as tenths is assumed (1-10, starting with very low results, through medium, up to very high scores).

2. Formal Characteristics of Behaviour: Temperament Inventory Revised Version (FCZ-KT (R)) developed by Bogdan Zawadzki and Jan Strelau, based on the regulatory temperament theory (RTT) (Zawadzki, \& Strelau, 1998) and containing 120 items referring to behaviour in various situations. The items form the following 6 scales: briskness - a predisposition to quick changes in behaviour adequate to the changing situation; perseverance - the ability to maintain specific behaviour despite the changing situation; sensory sensitiveness - the ability to react to sensory stimuli of a low stimulation value; emotional reactivity - the tendency to react with emotions to stimuli that provoke them; endurance - the ability to react correctly in situations requiring prolonged or intensely stimulating activity; activity 
- the tendency to seek intensely stimulating situations. For each trait, the score ranges from 0 to 20 points.

3. The Coping Inventory for Stressful Situations (CISS) developed by N.S. Endler and J.D.A. Parker, adapted to Polish conditions by Strelau, Jaworowska, Wrześniewski and Szczepaniak, serving the evaluation of coping styles used in stressful situations (Strelau, Jaworowska, Wrześniewski, \& Szczepaniak, 2009). The questionnaire contains 48 statements related to behaviour of people in stressful situations. Each of them refers to one of the following three scales: the task-oriented (TO) style describing the predisposition to undertake tasks and efforts aimed at solving a problem in stressful situations; the emotion-focused (EF) style describing the tendency to focus on emotions experienced in stressful situations; and the avoidance-oriented (AO) style. The last of those styles characterizes persons who present tendency to avoid thinking, experiencing and going through stressful situations. This style may take either of two forms - distraction (D), for example watching TV, overeating, thinking about pleasant things, dreaming or social diversion (SDS). Each scale is assigned 16 statements, and the result obtained for each of them ranges from 16 to 80 points.

The study was approved by the local Ethics Committee at the Ludwik Rydygier Memorial Collegium Medicum in Bydgoszcz, Nicolaus Copernicus University, Torun and, as the above research has been conducted on the human participants, it has been conducted ethically according to the principles of the Declaration of Helsinki.

Statistical analyses were performed with the Statistica 12.0 package. The results are presented as arithmetic means with standard deviations (SD). A relationship between variables was also estimated with the Spearman's rank correlation coefficient $(\rho)$. The assumed confidence level was $\alpha=0.05$.

\section{RESULTS}

The sample size included 58 volunteers - fire brigade officers, ranging from 23 to 50 years $(M=32.62$ years; $S D=6.74)$. The subjects met the following criteria for enrolment into the study group: (a) sex: male, (b) active service as a fire brigade officer, (c) positively evaluated health status following a standard comprehensive physical examination. Psychological tests were completed by the subjects in the presence of a psychologist, who answered all doubts and questions. The mean time for completing the questionnaire was below 60 minutes. Descriptive statistics for analysed variables are presented in Table 1. 
Table 1.

Descriptive statistics for studied variables

\begin{tabular}{lcccccc}
\hline & N Value & Mean & Median & Min. & Max. & SD \\
\hline $\begin{array}{l}\text { FCZ - KT - } \\
\text { briskness }\end{array}$ & 58 & 15.98 & 16.50 & 7.00 & 20.00 & 3.13 \\
\hline $\begin{array}{l}\text { FCZ - KT - } \\
\text { perseverance }\end{array}$ & 58 & 9.31 & 9.00 & 0.00 & 19.00 & 4.66 \\
\hline $\begin{array}{l}\text { FCZ - KT - sensory } \\
\text { sensitiveness }\end{array}$ & 58 & 14.50 & 15.00 & 5.00 & 20.00 & 3.69 \\
\hline $\begin{array}{l}\text { FCZ - KT - } \\
\text { emotional } \\
\text { reactivity }\end{array}$ & 58 & 6.66 & 7.00 & 0.00 & 20.00 & 4.57 \\
\hline $\begin{array}{l}\text { FCZ - KT - } \\
\text { endurance }\end{array}$ & 58 & 12.98 & 14.00 & 1.00 & 20.00 & 5.16 \\
\hline $\begin{array}{l}\text { FCZ - KT - } \\
\text { activity }\end{array}$ & 58 & 12.26 & 13.00 & 1.00 & 22.00 & 5.27 \\
\hline $\begin{array}{l}\text { FCZ - KT - } \\
\text { neuroticism }\end{array}$ & 58 & 14.79 & 15.00 & 3.00 & 33.00 & 6.27 \\
\hline $\begin{array}{l}\text { NEO - FFI - } \\
\text { extraversion }\end{array}$ & 58 & 30.34 & 31.00 & 3.00 & 43.00 & 6.88 \\
\hline $\begin{array}{l}\text { NEO - FFI - } \\
\text { openness to } \\
\text { experience }\end{array}$ & 58 & 24.03 & 25.00 & 12.00 & 32.00 & 3.82 \\
\hline $\begin{array}{l}\text { FCZ - KT - } \\
\text { agreeableness }\end{array}$ & 58 & 30.09 & 30.00 & 13.00 & 38.00 & 4.90 \\
\hline $\begin{array}{l}\text { FCZ - KT - } \\
\text { conscientiousness }\end{array}$ & 58 & 33.95 & 34.00 & 17.00 & 44.00 & 5.47 \\
\hline $\begin{array}{l}\text { CISS - TO } \\
\text { CISS - EF }\end{array}$ & 58 & 58.76 & 59.00 & 47.00 & 73.00 & 5.93 \\
\hline CISS - AO & 58 & 43.19 & 36.00 & 16.00 & 54.00 & 6.96 \\
\hline $\begin{array}{l}\text { CISS - D } \\
\text { CISS - SDS }\end{array}$ & 58 & 17.67 & 17.00 & 16.00 & 98.00 & 10.51 \\
\hline
\end{tabular}

At the next stage of the study, personality and temperament traits were correlated with coping styles for stressful situations, using the Spearman's rank correlation coefficient $(\rho)$. The results are shown in Tables 2-4. 


\section{Table 2.}

Analysis of the correlation between scores obtained from the Coping Inventory for Stressful Situations (CISS) and the Temperament Questionnaire (FCZ-KT). Statistically significant results are in bold.

\begin{tabular}{lccccc}
\hline & TO & EF & AO & D & SDS \\
\hline \multirow{2}{*}{ Briskness } & 0.1625 & $\mathbf{- 0 . 3 9 2 6}$ & 0.0845 & 0.1138 & 0.2742 \\
& $\mathrm{p}=0.223$ & $\mathbf{p}=\mathbf{0 . 0 0 2}$ & $\mathrm{p}=0.528$ & $\mathrm{p}=0.395$ & $\mathrm{p}=0.073$ \\
\hline & 0.1581 & $\mathbf{0 . 5 1 1 5}$ & 0.2258 & 0.0287 & 0.0611 \\
& $\mathrm{p}=0.236$ & $\mathbf{p}=\mathbf{0 . 0 0 0}$ & $\mathrm{p}=0.088$ & $\mathrm{p}=0.831$ & $\mathrm{p}=0.648$ \\
\hline Sensory & -0.0128 & 0.0106 & 0.1680 & 0.0578 & 0.1597 \\
& $\mathrm{p}=0.924$ & $\mathrm{p}=0.937$ & $\mathrm{p}=0.207$ & $\mathrm{p}=0.667$ & $\mathrm{p}=0.231$ \\
\hline Emotional & -0.2473 & $\mathbf{0 . 4 9 2 7}$ & 0.0959 & 0.0399 & -0.1602 \\
reactivity & $\mathrm{p}=0.061$ & $\mathbf{p}=\mathbf{0 . 0 0 0}$ & $\mathrm{p}=0.474$ & $\mathrm{p}=0.766$ & $\mathrm{p}=0.230$ \\
\hline \multirow{2}{*}{ Endurance } & -0.0460 & $\mathbf{- 0 . 5 4 0 8}$ & -0.1872 & 0.0280 & 0.0052 \\
& $\mathrm{p}=0.732$ & $\mathbf{p}=\mathbf{0 . 0 0 0}$ & $\mathrm{p}=0.159$ & $\mathrm{p}=0.835$ & $\mathrm{p}=0.969$ \\
\hline \multirow{2}{*}{ Activity } & 0.1978 & -0.2408 & 0.1981 & 0.1157 & 0.3709 \\
& $\mathrm{p}=0.137$ & $\mathrm{p}=0.069$ & $\mathrm{p}=0.136$ & $\mathrm{p}=0.387$ & $\mathrm{p}=0.400$ \\
\hline
\end{tabular}

The study results indicate that the emotion-focused coping style for stressful situations (EF) correlates positively with perseverance and with emotional reactivity (FCZ-KT), and negatively with briskness and endurance (FCZ-KT).

\section{Table 3.}

Analysis of the correlation between scores in the Coping Inventory for Stressful Situations (CISS) and the Temperament Questionnaire (FCZ-KT). Statistically significant results are in bold.

\begin{tabular}{lccccc}
\hline & TO & EF & AO & $\mathbf{D}$ & SDS \\
\hline \multirow{2}{*}{ Neuroticism } & $\mathbf{- 0 . 3 3 6 8}$ & $\mathbf{0 . 4 1 5 0}$ & 0.0996 & 0.0998 & 0.0160 \\
& $\mathbf{p}=\mathbf{0 . 0 1 0}$ & $\mathbf{p}=\mathbf{0 . 0 0 1}$ & $\mathrm{p}=0.457$ & $\mathrm{p}=0.456$ & $\mathrm{p}=0.905$ \\
\hline \multirow{2}{*}{ Extraversion } & $\mathbf{0 . 3 2 3 6}$ & -0.1860 & 0.2296 & 0.2056 & 0.4982 \\
& $\mathbf{P}=\mathbf{0 . 0 1 3}$ & $\mathrm{p}=0.162$ & $\mathrm{p}=0.083$ & $\mathrm{p}=0.122$ & $\mathrm{p}=0.056$ \\
\hline Openness to & 0.1074 & -0.1555 & 0.0627 & -0.0808 & 0.1386 \\
experience & $\mathrm{p}=0.422$ & $\mathrm{p}=0.244$ & $\mathrm{p}=0.640$ & $\mathrm{p}=0.546$ & $\mathrm{p}=0.299$ \\
\hline \multirow{2}{*}{ Agreeableness } & -0.0561 & -0.1405 & 0.0643 & -0.1492 & 0.0638 \\
& $\mathrm{p}=0.676$ & $\mathrm{p}=0.293$ & $\mathrm{p}=0.632$ & $\mathrm{p}=0.264$ & $\mathrm{p}=0.634$ \\
\hline \multirow{2}{*}{ Conscientiousness } & $\mathbf{0 . 3 0 8 8}$ & -0.2222 & 0.2385 & 0.0091 & 0.2429 \\
& $\mathbf{p}=\mathbf{0 . 0 1 8}$ & $\mathrm{p}=0.094$ & $\mathrm{p}=0.071$ & $\mathrm{p}=0.946$ & $\mathrm{p}=0.066$ \\
\hline
\end{tabular}


The study results indicate that the task-oriented coping style for stressful situations (TO) correlates positively with extraversion and with conscientiousness (NEO-FFI), and negatively with neuroticism (NEO-FFI). The emotionfocused coping style for stressful situations $(\mathrm{EF})$ is positively correlated with neuroticism (NEO-FFI).

\section{DISCUSSION}

This study on personality traits in the group of fire brigade officers showed that conscientiousness was the most pronounced trait, reflecting their attitude to work, the level of organization, persistence and motivation in activities focused on the objective (Hołda, 2009). The lowest results were obtained for neuroticism. This type of personality is characterised by high excitability, emotional lability, and susceptibility to negative emotions (anxiety, dejection, remorse), as well as depression, hostility, shyness, and hypersensitivity (Strelau, \& Zawadzki, 2000). Neurotic people have a low resistance to stress, low self-esteem, and problems with adaptation; they also function below their abilities. Neuroticism is the main factor responsible for the occurrence of PTSD (Oginska-Bulik, \& Langer, 2007). In the studied group, an analysis of temperament characteristics showed that briskness, i.e. the predisposition to quick changes in behaviour, was the most pronounced trait. At the same time, the researchers demonstrated that emotional reactivity was the least pronounced characteristic. High emotional reactivity is understood as a tendency for intense reactions to stimuli, manifested as high sensibility and low resistance. On the other hand, low reactivity is associated with low sensibility and high endurance. Emotional reactivity mainly concerns negative emotions, particularly fear. It is associated with the characteristics of emotional reaction combined with performance effectiveness. People in whom this trait is highly pronounced are characterised by emotional excitability, that is, they easily react with strong emotions, and by low emotional endurance. They will have a tendency for a lower performance in stressful situations (Strelau, 2000).

The body reactions to stress are individual characteristics depending, amongst other things, personality. The importance of this problem is emphasised in relevant publications, including a concept that for a person to be wellprepared for stressful situations, it is significant that they have the capability of drawing from different strategies and using them flexibly (Riolli, \& Savicki, 2010; Cheng, Lau, \& Chan, 2014; Carver, \& Scheier, 1994). Meta-analyses focusing on relations between personality and strategies for coping with stress indicate that extraversion is more commonly associated with a solution-focused behaviour, while neuroticism is a predictor for emotional coping (ConnorSmith, \& Flachsbart, 2007; Costa, Somerfield, \& McCraem, 1996; Skomorovsky, 2013). This is confirmed by study results indicating that the task-oriented coping style for stressful situations correlates positively with extraversion and with conscientiousness, and negatively with neuroticism. 
The emotion-focused coping style for stressful situations proved to have the strongest positive correlation with perseverance and emotional reactivity, and they were the least common temperament traits in the studied group. It was shown that the lower the tendency for prolonged experience of emotions - even when the situation initially inducing them changes - and the lower the tendency to react with emotions in situations inducing them, the lower the tendency to increase the sense of stress, emotional tension and dejection. It can be assumed, therefore, that the described relationship plays an adaptive role in the work of studied fire-fighters, and ensures effective reactions in difficult situations.

These results are consistent with Polish studies in a group of people at a risk of experiencing and developing symptoms associated with trauma, including fire brigade officers. The authors indicate that both perseverance and emotional reactivity may represent risk factors for the development of anxiety or post-traumatic stress disorders (Oniszczenko, 2010).

Furthermore, the conducted research demonstrated a negative correlation between the emotion-focused coping style for stressful situations, and the traits of briskness and endurance that prevailed in the group. The higher the predisposition for quick changes in behaviour adequate to the situation, and the higher the ability to react correctly in situations requiring prolonged or intensely stimulating activity, the lower the tendency to react to stress ineffectively, with anger directed at other people, self-accusations or escaping into daydreaming. In high-risk professions, such as firefighting, these temperament characteristics may help to correctly cope with highly stressful situations.

Interestingly, the study did not show factors correlated with the avoidance style. By definition, it can pose a significant risk for the person's wellbeing as it can assume the form of helplessness, withdrawal or substance abuse when the person is confronted with a difficult situation (Holahan, 1986).

The firefighting job, particularly in rescue and firefighting teams, is associated with a significant risk to health, both physical and mental. Difficult working conditions cannot be completely eliminated; therefore, our knowledge about the important role played by personality and temperament traits may be used to specify correct criteria for professional selection during the recruitment process. It is important to consider the factors associated with personality and temperament from the point of view of health-promoting activities at workplaces, with a particular focus on raising employee awareness about correct lifestyle. In this area, the strategies should also include introduction of psychological training developing emotional stability and resistance to stress.

\section{STUDY LIMITATIONS}

The study was conducted only in a group of men; therefore, it is difficult to extrapolate its results on the remaining part of the firefighting community. Furthermore, this study focuses only on an analysis of a correlation between personality traits and temperament and coping styles, and so the obtained results 
cannot be used to draw conclusions about a direction of influence of the studied variables. Moreover, it would be interesting to analyse how the concurrence of analysed variables is shaped in time. Concluding, there is a need for further studies that would include both sexes, and focus on the effect of increasing seniority on the intensity of personality traits, temperament and coping styles.

\section{CONCLUSIONS}

Summarizing all results received the answers to the research questions could be provided. First of all, in the examined group of fire brigade officers conscientiousness is the highest rated trait, and neuroticism is the lowest. As for the characteristics of temperament, briskness is the highest rated variable, while emotional reactivity is the lowest.

Answering the second research question regarding the correlation between temperament, personality characteristics and coping style for stressful situations in the studied group, the following was demonstrated:

1. A positive correlation between the emotion-focused coping style for stressful situations (EF) and perseverance and emotional reactivity was indicated. EF coping style coexisted with perseverance and emotional reactivity traits.

2. Results show a negative correlation of EF with briskness and endurance. The higher the EF result, the lower results of briskness and endurance traits.

3. A positive correlation between the task-oriented coping style for stressful situations (TO) and extraversion and conscientiousness was shown: the higher the breadth of activities, coming from external and energy creation from external means and scrupulousness, the higher results of TO coping style.

4. TO negatively correlated with neuroticism: the higher the rate of neuroticism the lower result in TO coping style.

5. A positive correlation was shown between the EF and neuroticism. The higher the rate of neuroticism, the higher the result in the EF coping style.

\section{REFERENCES}

1. Carver, C. S., \& Scheier, M. F. (1994). Situational coping and coping dispositions in a stressful transaction. Journal of personality and social psychology, 66(1), 184.

2. Carver, C. S., \& Connor-Smith, J. (2010). Personality and coping. Annual review of psychology, $61,679-704$.

3. Cheng, C., Lau, H. P. B., \& Chan, M. P. S. (2014). Coping flexibility and psychological adjustment to stressful life changes: A meta-analytic review. Psychological Bulletin, 140(6), 1582-1607.

4. Connor-Smith, J. K., \& Flachsbart, C. (2007). Relations between personality and coping: a meta-analysis. Journal of personality and social psychology, 93(6), 1080.

5. Costa, P. T., Somerfield, M. R., \& McCraem R. R. (1996) Personality and coping: a reconceptualisation. In: Zeidner, M., \& Endler, N.S. (eds.). Handbook of doping. Theory, research, applications (pp. 44-58). New York: Wiley. 
6. Holahan, C. J., \& Moos, R. H. (1986). Personality, coping, and family resources in stress resistance: A longitudinal analysis. Journal of personality and social psychology, 51(2), 389.

7. Hołda, M. (2009). Diagnoza osobowości. Inwentarz NEO-PI-R w teorii i praktyce [Diagnosis of personality. NEO-PI-R inventory in theory and practice]. Warszawa; Pracownia Testów Psychologicznych PTP: 93-109.

8. Klonowicz, T., \& Cieslak, R. (2004). Osobowość a ekstremalny stres [Personality and extreme stress]. Gdańsk; GWP.

9. Oginska-Bulik, N. (2005). The role of personal and social resources in preventing adverse health outcomes in employees of uniformed professions. International journal of occupational medicine and environmental health, 18(3), 233-240.

10. Ogińska-Bulik, N., \& Langer, I. (2007). Osobowość typu D i strategie radzenia sobie ze stresem a nasilenie objawów PTSD w grupie strażaków [Type D personality and strategies of coping with stress and intensity of PTSD symptoms among firefighters]. Medycyna Pracy, 58(4), 307-316.

11. Oniszczenko, W. (2010). Związek temperamentu w ujęciu regulacyjnej teorii temperamentu $\mathrm{z}$ objawami zaburzenia stresowego pourazowego w różnych grupach poszkodowanych. [Association of temperament in terms of regulatory temperament theory of posttraumatic stress disorder symptoms in different groups of victims]. Neuropsychiatria i Neuropsychologia, $5(1), 10-17$.

12. Riolli, L., \& Savicki, V. (2010). Coping effectiveness and coping diversity under traumatic stress. International Journal of Stress Management, 17(2), 97.

13. Rowe, M. M. (1997). Hardiness, stress, temperament, coping, and burnout in health professionals. American Journal of Health Behavior, 21(3), 163-171.

14. Skomorovsky, A. (2013). Psychological well-being of Canadian forces officer candidates: The role of personality and coping strategies. Military Psychology, 25(1), 3.

15. Strelau, J. (2000). Psychologia, Podręcznik akademicki, vol. 2. Gdańsk: GWP, 683-719.

16. Strelau, J., Jaworowska, A., Wrześniewski, K., \& Szczepaniak, P. (2009). Kwestionariusz Radzenia Sobie w Sytuacjach Stresowych CISS [Coping Inventory for Stressful Situations CISS]. Warszawa; Pracownia Testów Psychologicznych PTP.

17. Strelau, J., \& Zawadzki, B. (2000). Psychologia różnic indywidualnych [Psychology of individual differences]. In: Strelau, J., \& Doliński, D. (eds.). Psychologia. Podręcznik akademicki. Psychologia różnic indywidualnych [Psychology. Academic handbook. Psychology of individual differences] (pp. 765-845). Gdańsk: GWP.

18. Zawadzki, B., \& Strelau, J. (1998) Formalna Charakterystyka Zachowania - Kwestionariusz Temperamentu (FCZ - KT) [Formal Characteristics of Behaviour - Questionnaire of Temperament (FCZ - KT)]. Pracownia testów Psychologicznych Polskiego Towarzystwa Psychologicznego. Warszawa; Pracownia Testów Psychologicznych PTP.

19. Zawadzki, B., Strelau, J., Szczepaniak, J., \& Śliwińska, M. (1998). Inwentarz Osobowości NEO-FFI Costy and McCrae. Polish adaptation [Personality Inventory NEO-FFI Costy and McCrae. Polish adaptation]. Warszawa; Pracownia Testów Psychologicznych PTP. 